Vietnam Journal of Earth Sciences, 38(4), 317-326, DOI: 10.15625/0866-7187/38/4/8713

Vietnam Academy of Science and Technology
(VAST)

\title{
Quantifying organic carbon storage and sources in sediments of Dong Rui mangrove forests, Tien Yen district, Quang Ninh province using carbon stable isotope
}

\author{
Pham Thao Nguyen, Nguyen Tai Tue*, Tran Dang Quy, Nguyen Dinh Thai \\ Faculty of Geology, VNU University of Science
}

Received 1 June 2016. Accepted 20 August 2016

\begin{abstract}
The objective of this study is to quantify the organic carbon (OC) storage and its sources in sediments of Dong Rui mangrove forests, Tien Yen district, Quang Ninh province by analyzing TOC (total organic carbon), TN (total nitrogen), $\mathrm{C} / \mathrm{N}$ ratios, $\delta^{13} \mathrm{C}$ isotopes and sediment grain sizes. The results showed that the fine-grained sediment fraction $(<63 \mu \mathrm{m})$ ranged from 8.58 to $82.10 \%$; TOC, TN contents, $\mathrm{C} / \mathrm{N}$ ratios and $\delta^{13} \mathrm{C}$ values ranged from 0.21 to $10.20 \%, 0.01$ to $0.34 \%, 15.07$ to 46.09 and -27.75 to $-25.84 \%$, respectively. The variation of $\delta^{13} \mathrm{C}$ and $\mathrm{C} / \mathrm{N}$ ratios, and the correlation between TOC, TN and the fine-grained sediment fractions indicated that mangrove forests play important roles in OC sequestration and accumulation of fine-grained sediments. The OC storage in sediments varied from 16.7 to $78.3 \mathrm{MgC} \mathrm{ha}^{-1}$ with an average of $57.2 \pm 14.9 \mathrm{MgC} \mathrm{ha}^{-1}$. Nowadays, the mangrove forest area in Dong Rui is about 2194.1 ha, thus, the total $\mathrm{OC}$ in sediment pool up to $45 \mathrm{~cm}$ in depth, contained $1.26( \pm 0.3) \times 10^{5} \mathrm{MgC}$, equivalent to $4.6( \pm 1.2) \times 10^{5} \mathrm{Mg} \mathrm{CO}_{2}$. These results demonstrated that the conservation of Dong Rui mangrove forest not only provides opportunities for coastal protection and disaster mitigation and other provision values, but also enhancing carbon sequestration and offsetting greenhouse gas emissions.
\end{abstract}

Keywords: mangrove forest, sediment, organic carbon, stable isotope, Dong Rui.

(C)2016 Vietnam Academy of Science and Technology

\section{Introduction}

Mangrove forests distribute in the transitional zone between the continent and the sea in tropical and subtropical regions. Vietnam has a coastline of $3,260 \mathrm{~km}$ and large river deltas, estuaries that provide favorable conditions for mangrove development.

*Corresponding author, Email: tuenguyentai@vnu.edu.vn
Mangrove forests of Vietnam provide many ecosystem functions and services such as mitigation of natural hazards (i.e., typhoons, floods and coastal erosion), supply food sources for a large variety of invertebrates, fish and waterfowls, and contribute to livelihoods for coastal communities (Alongi, 2011). Despite their importance to economic and social development, mangroves have been destroyed at an alarming rate since 1980s. 
Pham Thao Nguyen, et al./Vietnam Journal of Earth Sciences 38 (2016)

Nearly $25 \%$ of the natural mangrove forests have been lost as a result of human intervention such as urbanization, development of aquaculture and agriculture (Spalding et al., 2010). Subsequently, the decline of mangrove forests has caused adverse impacts on the environment, for example, greenhouse gas emissions (Donato et al., 2011; Lovelock et al., 2011), biodiversity degradation (Nguyen et al., 2014), and increased the damage by coastal erosion and loss of livelihoods of people in coastal areas (Richard et al., 2011).

Due to fast urbanization and industrial development, the greenhouse gases (GHG) emissions are reported to increase with larger amplitude (Richard et al., 2011). In order to restrain increase in $\mathrm{GHG}$, concentrations in the atmosphere, the Kyoto Protocol (1997) and Paris Agreement on Climate Change (2015) were adopted by the international community committed to reducing $\mathrm{GHG}$ emissions. These agreements become the legal basis for the implementation of the GHG reduction by using various solutions and mechanisms. In which, Clean Development Mechanism allows developed countries to achieve their targets on reducing GHG emissions through investigation of reforestation projects in the developing countries.

Mangrove forests are suitable place to sequester a larger carbon amount than the other forests (Christensen, 1978) and considered as crucial carbon sinks in globally coastal systems (Kristensen et al., 2008; Ong, 1993). On average, one hectare of mangrove forests contains approximately $470 \mathrm{Mg} \mathrm{C}$. With a total area of $139,170 \mathrm{~km}^{2}$ globally, mangrove forests can store about $6.5 \mathrm{Pg} \mathrm{C}$, equivalent to $24 \mathrm{Pg}$ of $\mathrm{CO}_{2} \mathrm{e}$ (Siikamäki et al., 2012). Particularly, a large proportion of carbon storage is preserved in sedimentary stratum (Donato et al., 2011; Nguyen et al., 2014). Therefore, the sedimentary organic carbon (OC) plays an important role in the global carbon cycle and reducing GHG emissions. However, study of the quantification of $\mathrm{OC}$ storage and sources in mangrove sediments has not been widely conducted in Vietnam. Therefore, the objectives of the present study are to quantify OC storage and to examine the sources of OC in sediments of Dong Rui mangrove forest area, Tien Yen District, Quang Ninh province. The outcomes will provide crucial information for understanding the role of mangrove forests in sequestration of $\mathrm{OC}$ and offsetting GHGs.

\section{Materials and methods}

\subsection{Study area}

The present study was carried out in Dong Rui mangrove forests, Tien Yen district, Quang Ninh province. The Dong Rui commune is located between Voi Lon and $\mathrm{Ba}$ Che creeks (Figure 1). The area of Dong Rui commune is about 5,000 ha, of which 2194.1 ha are covered by mangrove forests. The mangrove forests are unique primeval in Vietnam. The floristic compositions dominate by Bruguiera gymnorrhiza, Rhizophora stylosa, Kandelia obovata, Avicennia marina, Aegiceras corniculatum with tree's height is less than $6 \mathrm{~m}$, the maximum diameter breast height $\leq 25 \mathrm{~cm}$. The mangrove forests are obviously high in biodiversity level, ecological functions and environmental protection, on the one hand, and providing various economic values, directly supporting the livelihood for local communities (i.e., shrimp, bivalves, crabs, peanut worm, etc.), on the other.

\subsection{Field sampling}

Fieldwork was conducted from 24 to 29 March, 2016 in Dong Rui mangrove forests. Three sediment cores were collected from different mangrove forest types, consisting of the fringe mangrove forests along Voi Lon creek (core $\mathrm{C} 1$ ), the mangrove forest in isle of 
Vietnam Journal of Earth Sciences, 38(4), 297-306

Voi Lon River (core C2) and the mangrove forest in downstream of $\mathrm{Ba}$ Che River adjacent to Mui Chua (core C3) (Figure 1). Sediment cores were taken by a hand corer with a PVC inner tube $(30 \mathrm{~cm}$ in length and $10 \mathrm{~cm}$ diameter). The lengths of sediment cores $\mathrm{C} 1, \mathrm{C} 2, \mathrm{C} 3$ were $45 \mathrm{~cm}, 32 \mathrm{~cm}$ and $40 \mathrm{~cm}$, respectively. Immediately following collection, sediment cores were caped and stored in upright position and maintained in cool condition. Sediment cores were processed within $12 \mathrm{~h}$ of collection by first removing the outer crust $(0.5 \mathrm{~cm}$ in thickness), then slicing into 3 and $5 \mathrm{~cm}$ intervals for the core depths intervals of $0-15$ and $15-45 \mathrm{~cm}$, respectively. The sediment samples were packed in labeled polyethylene bags for further analysis. All sediment samples were maintained on ice in coolers and transported to the laboratory where they were frozen at $-20^{\circ} \mathrm{C}$ until further processing and analysis.

Samples identifying the potential of OC sources for mangrove sediments in the study area were collected, consisting of five fresh mangrove leave samples and five marine phytoplankton samples (POM). The samples were analyzed for $\mathrm{C} / \mathrm{N}$ and stable carbon isotope $\delta^{13} \mathrm{C}$ values. Mangrove leaves were carefully rinsed with distilled-deionized water soon after collecting to remove any extraneous materials. POM samples were collected by filtering $0.5-1.0 \mathrm{~L}$ of surface water $(0-2 \mathrm{~m}$ in depth) through pre-combusted (at $550^{\circ} \mathrm{C}$ ) $47 \mathrm{~mm}$ Whatman $\mathrm{GF} / \mathrm{F}$ glass fiber filters using a pressure pump. Filters were lightly rinsed by distilled-deionized water to remove salt residue, and stored on iceboxes then transported to the laboratory for further processing.

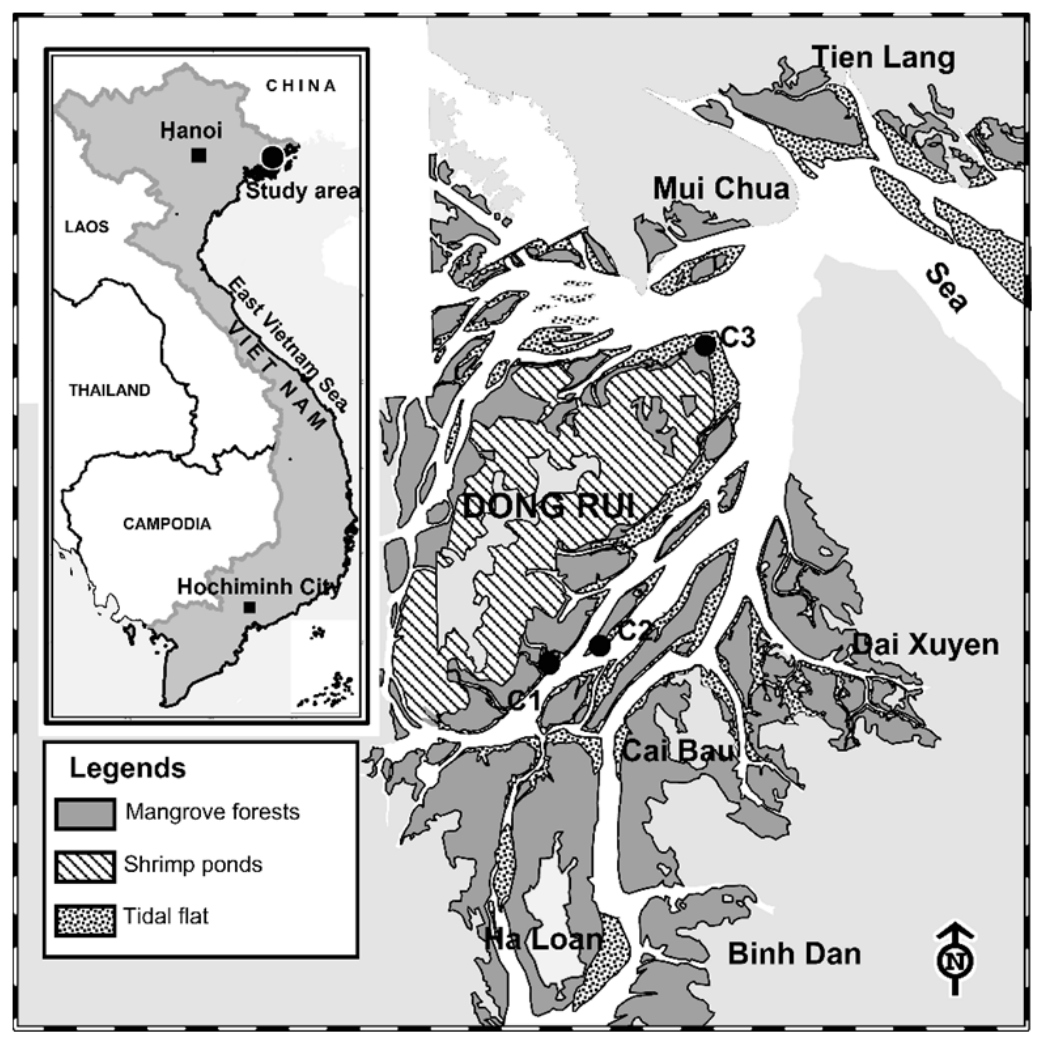

Figure 1. Sampling sites in Dong Rui mangrove forest 


\subsection{Sample preparation and analysis}

\subsubsection{Sediment grain size analysis}

Sediment grain size was analyzed using an automatic laser diffraction particle size analyzer LA-950V2 (HORIBA Co.). After booting 30 minutes, a computer program of the LA-950V2 was operated. About $1 \mathrm{~g}$ of fresh sediment sample was loaded into the machine chamber. After measurement, results of sediment grain size compositions, were printed or exported as pdf or csv files.

\subsubsection{Organic matter analysis}

Wet sediment samples $(10-20 \mathrm{~g})$ were weighed in porcelain cups and dried in an oven at $60^{\circ} \mathrm{C}$, then ground in an agate mill. During grinding, extraneous materials, including tree branches, roots and inorganic matter were manually removed.

The organic matter (OM) content was obtained via loss on ignition measurement. Two grams of the pulverized sediments was first dried at $100^{\circ} \mathrm{C}$ in a drying oven for $2 \mathrm{~h}$ and then heated at $550^{\circ} \mathrm{C}$ in a temperaturemonitored muffle furnace for $5 \mathrm{~h}$. OM content is calculated as the difference between the weight from before and after combustion at $550^{\circ} \mathrm{C}$ divided by the initial sample weight times $100 \%$.

2.3.3. Total organic carbon, total nitrogen and stable isotope $\delta^{13} C$ analysis

A total of $0.2 \mathrm{~g}$ of pulverized sediment sample was placed in an Eppendorf tube, added about $3 \mathrm{ml}$ of $1 \mathrm{~N} \mathrm{HCl}$, mixed thoroughly using a vibrating mixer, then left at room temperature for $24 \mathrm{~h}$ to remove carbonates. After acid treatment, the samples were repeatedly rinsed with $4 \mathrm{ml}$ milli-Q water, mixed in an ultrasonic bath, then centrifuged to separate from solutions. This process was repeated four times before being dried in an oven at $60^{\circ} \mathrm{C}$ for $48 \mathrm{~h}$. About 10 $\mathrm{mg}$ of the treated sediment sample was taken and wrapped into a tin cup sized $6 \times 4 \mathrm{~mm}$.

Stable isotope $\delta^{13} \mathrm{C}$, TOC and TN values were measured using an elemental analyzer (EA-EuroVector) connected to a stable isotope ratio mass spectrometry system (IRMS) (Nu Perspective). The samples were placed into the auto-sampler tray and introduced into the combustion chamber. In the combustion chamber, the sediments are converted into $\mathrm{CO}_{2}$ and $\mathrm{NO}_{2}$. The gases are sent to reduction column for making pure $\mathrm{CO}_{2}$ and $\mathrm{N}_{2}$ gases and separated by a gas chromatographic column and carried to the IRMS system. Here, the gases are ionized, passed through the electro-magnetic field and the carbon and nitrogen stable isotopes are collected and counted by the Faraday cups.

The precision and accuracy of the analysis were evaluated using a Urea isotopic standard B2174 (Microanalysis Co.). $\delta^{13} \mathrm{C}$ value was expressed in \%o (permil) deviations from the referenced standard value by the following Eq. 1:

$$
\delta^{13} \mathrm{C}(\% 0)=\left(\frac{\mathrm{R}_{\text {sample }}}{\mathrm{R}_{\text {standard }}}-1\right) \times 1000
$$

where $\mathrm{R}={ }^{13} \mathrm{C} /{ }^{12} \mathrm{C}, \mathrm{R}_{\text {sample }}$ is the isotope ratio of the sample and $R_{\text {standard }}$ is the isotope ratio of a standard referenced to Pee Dee Belemnite (PDB) limestone carbonate. The analytical error was $\pm 0.1 \%$ for $\delta^{13} \mathrm{C}$.

\subsection{Ecosystem C storage estimation procedure}

The sediment $\mathrm{C}$ pool was calculated following Eq. 2 (Nguyen et al., 2014):

Sediment $\mathrm{C}$ pool $\left(\mathrm{MgC} \mathrm{ha}{ }^{-1}\right)=\rho\left(\mathrm{gcm}^{-3}\right) \times$ TOC $(\%) \times \mathrm{h}(\mathrm{cm})(2)$

In which: $\rho$ is the bulk sediment density, TOC is the total organic carbon and $h$ is the depth interval. In this study, bulk sediment density was measured through TOC values based on the Eq. 3 (Nguyen et al., 2014): 
Bulk sediment density $=1.539 \mathrm{e}^{(-0.289 \times \text { TOC })}$ $\left(\mathrm{R}^{2}=0.62, \mathrm{p}<0.001, \mathrm{n}=225\right)(3)$

The total C storage of Dong Rui mangrove forest was scaled up by multiplying the mean ecosystem C storage $\left(\mathrm{MgC} \mathrm{ha}{ }^{-1}\right)$ with the total area of mangrove forest (2194.1 ha) and converted to carbon dioxide equivalents $\left(\mathrm{CO}_{2 \mathrm{e}}\right)$ using a factor of 3.67 (Kauffman and Donato, 2012).

\section{Results and discussion}

\subsection{Sediment characteristics}

Mangrove sediments were composed mainly of fine sand, silt and clay. The fraction smaller than $63 \mu \mathrm{m}$ or mud content varied from $9.48 \%$ to $56.07 \%$, with an average of $26.2 \%$ and tended to decrease with depth of the sediment cores. Average mud content in core $\mathrm{C} 1, \mathrm{C} 2$ and $\mathrm{C} 3$ was $37.36 \%, 37.43 \%$ and $24.83 \%$, respectively (Figure 2). High mud content in sediment cores located in fringe mangrove forests of Voi Lon river and in downstream $\mathrm{Ba}$ Che river (near Mui Chua estuary, see Figure 1) indicated that finegrained sediments being transported from $\mathrm{Ba}$ Che river mainly deposited in the fringe mangrove forests. Tide is an important factor for transporting particles in Voi Lon creek and $\mathrm{Ba}$ Che river into mangrove forests. From the fringe forest to interior forest, the decrease of tidal current energy was reduced by vegetation density and mangrove root systems of K. obovata, B. gymnornitreza and A. corniculatum (Furukawa and Wolanski, 1996). Consequently, the coarse-grained sediments mainly deposited at the fringe forest and only the fine-grained sediments were transported further into the interior forest areas (Van Santen et al., 2007).

\section{Mud content (\%)}

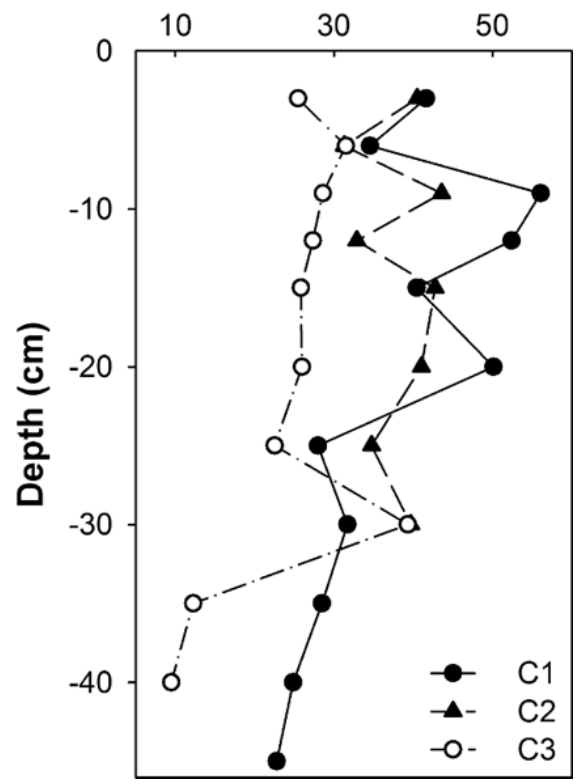

Figure 2. Mud content profiles in three sediment cores from Dong Rui mangrove forest

\subsection{Total organic carbon, organic matter content, $\mathrm{C} / \mathrm{N}$ ratios and carbon stable isotope $\left(\delta^{13} C\right)$}

The TOC contents ranged from 1.91 to $8.28 \%, 0.63$ to $10.20 \%$ and 0.21 to $8.57 \%$ for core $\mathrm{C} 1, \mathrm{C} 2$ and $\mathrm{C} 3$, respectively (Figure 3 ). The TN contents varied from 0.09 to $0.24 \%$, 0.04 to $0.34 \%$ and 0.01 to $0.25 \%$ for core $\mathrm{C} 1$, $\mathrm{C} 2$ and $\mathrm{C} 3$, respectively. Both TOC and TN contents tended to increase from the surface to $30 \mathrm{~cm}$ in depth and slightly decrease to the core bottom (Figure 3). Strongly positive correlation between TOC and TN (Figure 4) possibly reflect the source similarity of TOC and TN (Nguyen et al., 2011). Additionally, the regression line of TOC and TN approached very close to the origin $(0,0)$, suggesting that the inorganic nitrogen content in mangrove sediments was insignificant and the TN was mostly in organic nitrogen. Therefore, $\mathrm{TN}$ can be used to calculate atomic $\mathrm{C} / \mathrm{N}$ ratio and ascertain the origins of sedimentary OC (Lamb et al., 2006). 
Pham Thao Nguyen, et al./Vietnam Journal of Earth Sciences 38 (2016)
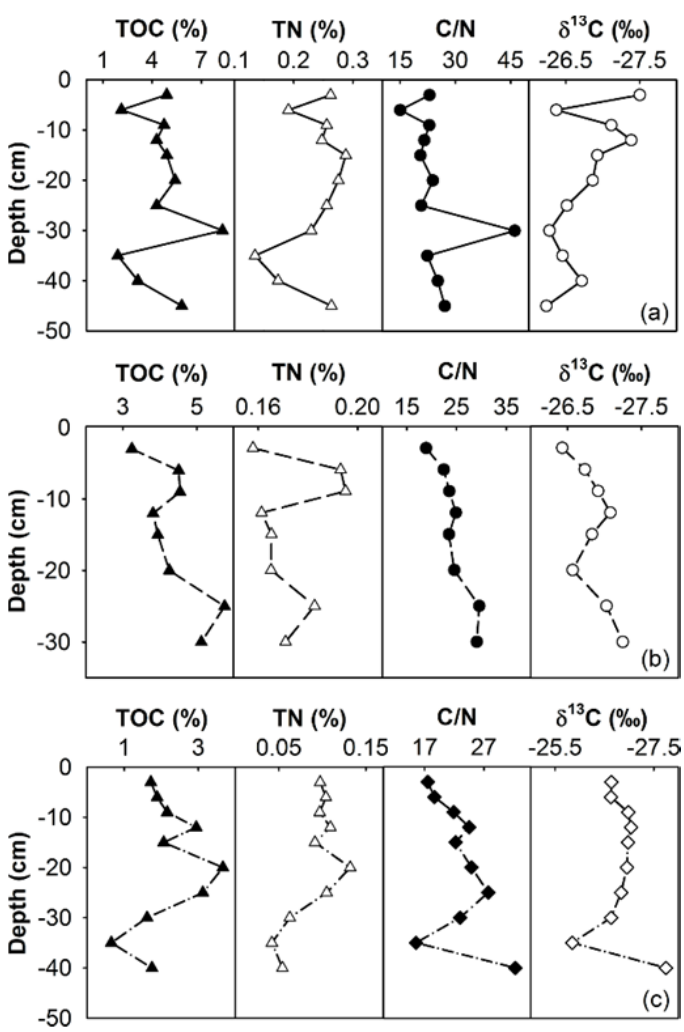

Figure 3. The variation of the TOC (\%), TN (\%), C/N ratio $(\mathrm{mol} / \mathrm{mol})$ and $\delta^{13} \mathrm{C}$ of the sediment cores. (a) fringe mangrove forest along Voi Lon creek (C1); (b) mangrove forests in isle of Voi Lon River (C2); (c) mangrove forest in downstream of $\mathrm{Ba}$ Che River adjacent to Mui Chua (C3)

Fine-grained sediment fractions were closely correlated with TOC $\left(\mathrm{R}^{2}=0.48\right)$ and $\mathrm{TN}\left(\mathrm{R}^{2}=0.40\right)$ contents (Figure 5). The low correlation coefficients indicated that other factors and fine-grained sediment fractions could also affect accumulation of $\mathrm{OM}$ contents in mangrove sediments, including sedimentation rates (Hedges and Keil, 1995; Reimers and Suess, 1983) and maturity levels of mangrove forests and intertidal elevation (Alongi et al., 2004). For example, the sedimentation rates could be an important factor for the preservation and storage of OM (Hedges and Keil, 1995; Reimers and Suess, 1983). These authors suggested that if the sedimentation rates are high, the $\mathrm{OM}$ will be burial faster and escaped from the microbial decomposition and preserve better. Maturity level of mangrove forests also affect sedimentary OM contents with higher sedimentary $\mathrm{OM}$ contents in mature mangrove forests in comparison to young forests (Alongi et al., 2004).

The OM content in mangrove sediments ranged from 2.56 to $17.31 \%$, with an average of $7.63 \pm 4.9 \%$. The $\mathrm{OM}$ is positively correlated with TOC content (Eq. 4, Figure 6): $\mathrm{TOC}(\%)=0.41 \times \mathrm{OM}(\%)+0.17\left(\mathrm{R}^{2}=0.79\right)(4)$

The results indicated that the TOC contents in sediments of Dong Rui mangrove forests could be estimated by the OM contents following Eq. 4. The linear regression model (Eq. 4) suggested that the application of the loss- on- ignition method (LOI method) for determining TOC in mangrove sediments by using Bemmelen factor of 0.58 (OC accounting 58\%) (Schumacher, 2002) should be performed with caution, because it can considerably overestimate the TOC content by approximately $17 \%$.

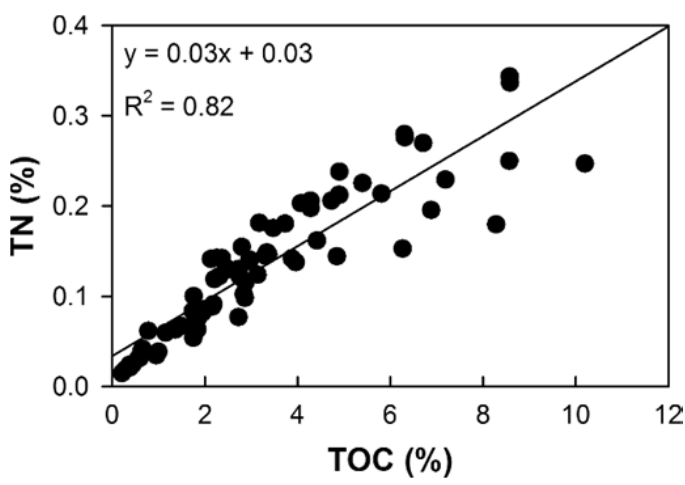

Figure 4. Linear regression of the TOC (\%) and TN (\%) for the mangrove sediments

The $\delta^{13} \mathrm{C}$ in core $\mathrm{C} 1$ ranged from -27.50 to $-26.24 \%$, with an average of $-26.76 \%$. The $\delta^{13} \mathrm{C}$ values were the lowest at surface sediments $(-27.50 \%)$ and gradually increased with sediment depth. The $\mathrm{C} / \mathrm{N}$ ratios varied from 15.07 to 46.09 , with an average of 24.45 . The ratios slightly increased from the surface 
to the bottom of the core and reached the highest value of 46.09 at $30 \mathrm{~cm}$ in depth (Figure 3a).

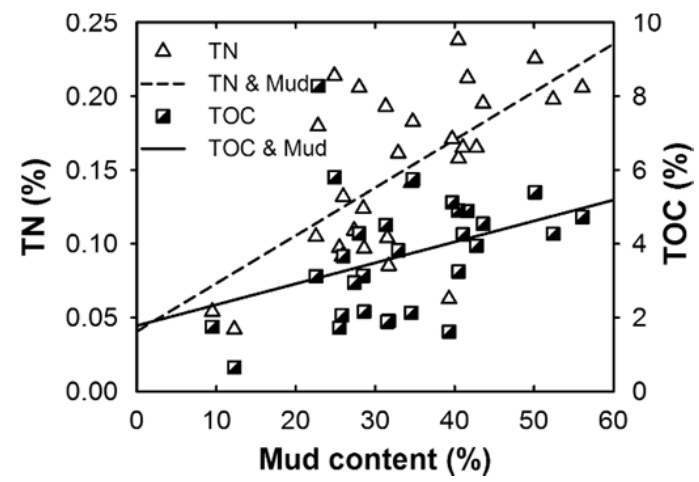

Figure 5. Correlation between $\mathrm{TOC}, \mathrm{TN}$ and finegrained sediment fraction in mangrove sediments

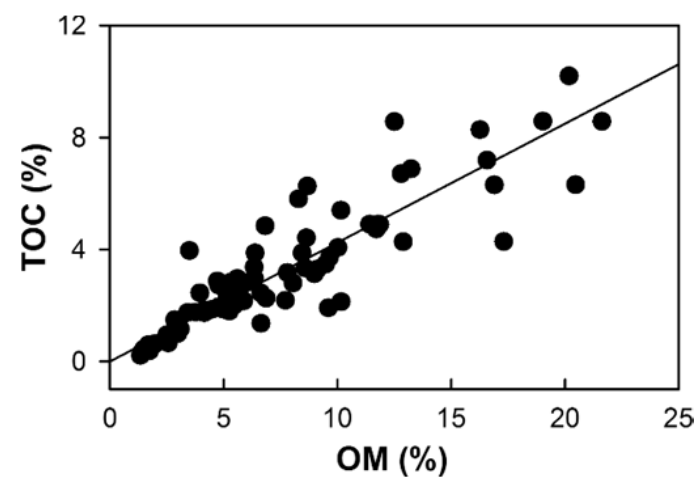

Figure 6. Correlation between TOC and $\mathrm{OM}$ in sediments from Dong Rui mangrove forest

For core $\mathrm{C} 2$, the $\mathrm{C} / \mathrm{N}$ ratios ranged from 18.88 to 29.57 , with an average of 24.56 . From the surface to the bottom core, C/N tended to increase and reached the maximal values of 29.57 at $25 \mathrm{~cm}$ in depth. The $\delta^{13} \mathrm{C}$ values ranged from -27.25 to $-26.43 \%$ with an average of $-26.85 \%$. From the surface to $12 \mathrm{~cm}$ in depth, $\delta^{13} \mathrm{C}$ slightly decreased from 27.25 to $-27.08 \%$, then rose to $-26.57 \%$ at 20 $\mathrm{cm}$ in depth, but thereafter decreased toward the bottom of the core (Figure $3 b$ ).

The $\mathrm{C} / \mathrm{N}$ ratios in core $\mathrm{C} 3$ ranged from 15.56 to 32.29 , with an average of 22.82 . From the surface to $25 \mathrm{~cm}, \mathrm{C} / \mathrm{N}$ increased from 17.53 to 27.72 , then decreased to the lowest value (15.56) at $35 \mathrm{~cm}$ in depth, then fluctuated to the core bottom. The $\delta^{13} \mathrm{C}$ values ranged from -27.75 to $-25.84 \%$, with an average of $-26.83 \%$. From the surface to the depth of $35 \mathrm{~cm}, \delta^{13} \mathrm{C}$ values slightly increased and reached the maximum value of $-25.84 \%$, then tended to increase to the core bottom (Figure 3c).

The variation of the $\mathrm{C} / \mathrm{N}$ ratios and $\delta^{13} \mathrm{C}$ values with depth in mangrove sediment cores indicated the change in the origin of OC and the degree of OM decomposition (Nguyen et al., 2011) and the absorption nitrogen by finegrained sediments at the top layers of mangrove sediment cores (Lamb et al., 2006).

\subsection{Sources of organic carbon in sediments}

Organic matters in the mangrove sediments were derived from local plants (termed as autochthonous sources) and other sources such as terrestrial organic matter, marine phytoplankton, and others, termed as allochthonous. Therefore, the determination of the OC sources in mangrove sediments will elucidate the role of mangroves in the carbon sequestration processes.

In mangrove forests, biomass of microalgae is generally low due to limited light and rich in tannin compounds released from the decomposition process of mangrove litters. Therefore, the major sources of OC in the mangrove sediments may consist mainly of mangrove litters and marine phytoplankton. Generally, $\delta^{13} \mathrm{C}$ values of mangrove litters ranged from -29.4 to $-27 \%$ and of the marine phytoplankton ranged from -22 to $-18 \%$ o (Bouillon et al., 2008; Bouillon et al., 2003). In addition, due to their high cellulose content, $\mathrm{C} / \mathrm{N}$ ratios of mangrove litters are commonly greater than 12, whereas marine phytoplankton is rich in nitrogen content and has relatively low $\mathrm{C} / \mathrm{N}$ ratios, ranging from 5 to 7 (Lamb et al., 2006). Thus, $\mathrm{C} / \mathrm{N}$ ratios and $\delta^{13} \mathrm{C}$ values were used to determine the sources of sedimentary OC.

In this study, the mean $\delta^{13} \mathrm{C}$ values of mangrove leaves and $\mathrm{C} / \mathrm{N}$ were $-28.84 \pm$ $1.09 \%$ o $(\mathrm{n}=5), 44.40 \pm 17.12(\mathrm{n}=5)$, respectively. The $\delta^{13} \mathrm{C}$ value of mangrove 
Pham Thao Nguyen, et al./Vietnam Journal of Earth Sciences 38 (2016)

leaves indicated the characteristics of $\mathrm{C} 3$ terrestrial plants and consistent with other mangrove species in Vietnam (Nguyen et al., 2012). The $\delta^{13} \mathrm{C}$ value and $\mathrm{C} / \mathrm{N}$ ratio of phytoplankton were $-23.46 \pm 0.34 \%$ and 9.20 \pm 0.10 , respectively (Figure 7). The relationship between $\mathrm{C} / \mathrm{N}$ and $\delta^{13} \mathrm{C}$ indicated that sedimentary OC in Dong Rui mangrove forest was composed of marine phytoplankton and mangrove litters (Figure 7). The $\delta^{13} \mathrm{C}$ values and $\mathrm{C} / \mathrm{N}$ ratios indicated that the sources of cores $\mathrm{C} 1$ and $\mathrm{C} 2$ were mangrove leaves, while the $\delta^{13} \mathrm{C}$ values and $\mathrm{C} / \mathrm{N}$ ratios in core $\mathrm{C} 3$ were close to those of phytoplankton (Figure 7). These results suggested that the sources of $\mathrm{OC}$ in cores $\mathrm{C} 1$ and $\mathrm{C} 2$ were delivered mostly from mangrove litters, while the sources of $\mathrm{OC}$ in core $\mathrm{C} 3$ were mainly from the marine phytoplankton (Figure 7). The finding was similar to previous report for mangrove forests in Tien Yen Bay, Quang Ninh (Tran and Nguyen, 2011).

The proportional contribution of mangrove litters and marine phytoplankton to sediments was determined by equation Eq. 5 (Nguyen et al., 2011):

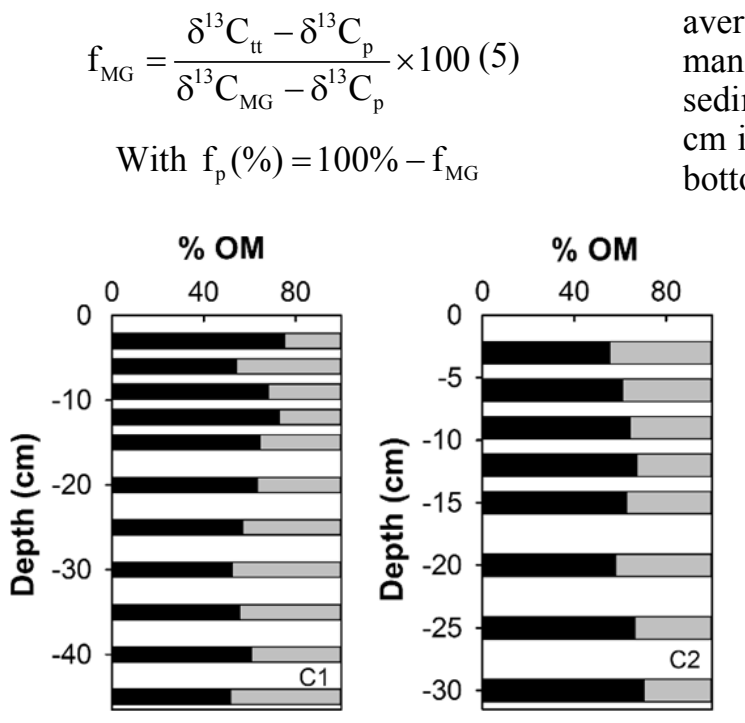

Figure 8. The percentage of OC contribution of mangrove litters $\left(f_{M G}\right)$ and phytoplankton $\left(f_{p}\right)$ where, $f_{p}, f_{M G}$ are the proportional contribution of mangrove litters and marine phytoplankton, respectively; $\delta^{13} \mathrm{C}_{\mathrm{sed}}, \delta^{13} \mathrm{C}_{\mathrm{p}}, \delta^{13} \mathrm{C}_{\mathrm{MG}}$ are the carbon stable isotope values of sedimentary $\mathrm{OC}$ and marine phytoplankton, respectively.

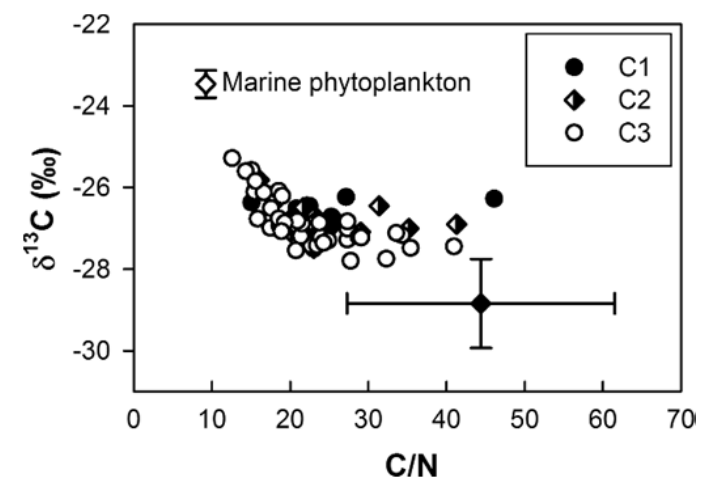

Figure 7. Comparison of $\mathrm{C} / \mathrm{N}$ ratios and $\delta^{13} \mathrm{C}$ values in mangrove sediments

The proportional contributions of the mangrove litters and marine phytoplankton in Dong Rui mangrove forests are shown in Figure 8 . The mangrove litter proportion in sedimentary OC varied from 44.32 to $79.72 \%$ with an average of $62.4 \%$. The marine phytoplankton contribution in sedimentary OC ranged from 20.28 to $55.68 \%$ with an average of $37.6 \%$. For all sediment cores, the mangrove litter contribution was higher in the sedimentary formation from surface to the 20 $\mathrm{cm}$ in depth and slightly decreased to the core bottom.

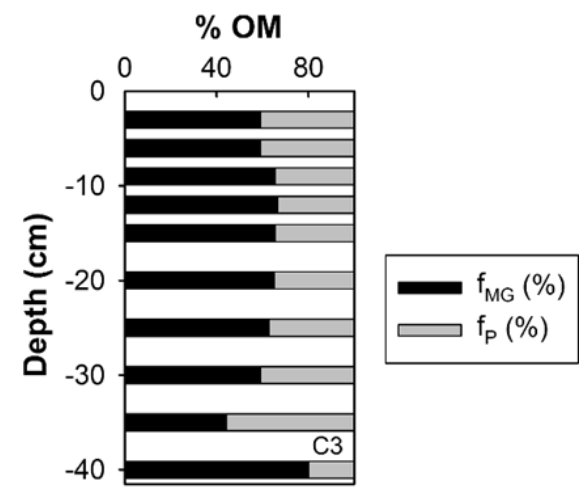


Vietnam Journal of Earth Sciences, 38(4), 297-306

\subsection{Ecosystem carbon storage of the mangrove forest}

The ecosystem $\mathrm{C}$ storage significantly decreased, respectively, 78.27, 46.72, 46.62 $\mathrm{MgC} \mathrm{ha}{ }^{-1}$ in estuarine mangrove forests, mangrove forests in river isle and mangrove forest adjacent to Mui Chua (Figure 9).

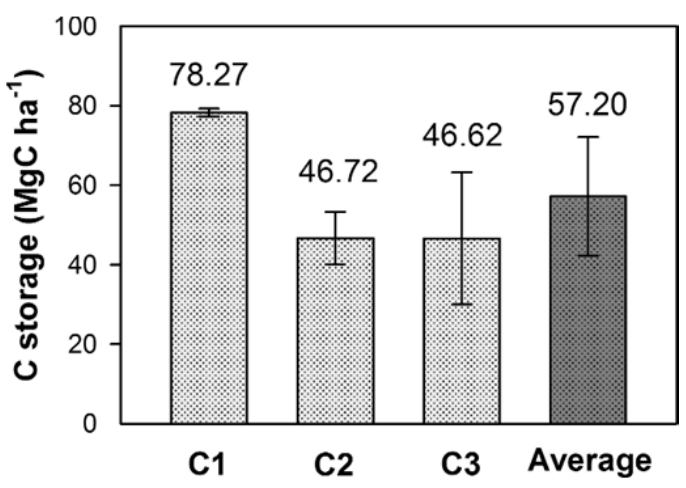

Figure 9. OC storage in Dong Rui mangrove forest. C1: fringe mangrove forest along Voi Lon creek; C2: mangrove forest in isle of Voi Lon River; C3: mangrove forest in downstream of $\mathrm{Ba}$ Che River adjacent to Mui Chua.

The overall mean of ecosystem $\mathrm{C}$ storage was estimated to be $57.2 \pm 14.9 \mathrm{MgC} \mathrm{ha}^{-1}$ in the Dong Rui mangrove forests that was similar to previous report for planted mangrove forests in the Giao Thuy district, Nam Dinh province (Mai and Nguyen, 2009). The mangrove forest area of 2194.1 ha in Dong Rui mangrove forests was estimated store upwards to $1.26 \times 10^{5} \mathrm{Mg}$ of $\mathrm{C}$ at $45 \mathrm{~cm}$ in depth, which can be converted to $4.6 \times 10^{5} \mathrm{Mg}$ of carbon dioxide equivalent $\left(\mathrm{CO}_{2} \mathrm{e}\right)$. If the whole mangrove forest area is to convert into other land uses (i.e., shrimp ponds or agricultural lands), a large amount of GHGs may be emitted into the atmosphere (Lovelock et al., 2011). Our results indicated that Dong Rui mangrove forests plays an important role in carbon sequestration and $\mathrm{OC}$ storage in sediments, reducing GHGs and mitigating effect of climate change. Therefore, the conservation of mangroves not only brings about visible benefits (i.e., wood and fishery production) but also lends effort in reduction of GHG emissions from deforestation. Mangrove forests, therefore, should be included in the program of 'reducing emissions from deforestation and forest degradation' (REDD +) (Donato et al., 2011) and suitable use schemes in the coastal zone (Hoang et al., 2012).

\section{Conclusions}

The present study showed that the fine sediment grained size fractions $(<63 \mu \mathrm{m})$ varied in a large range from 8.58 to $82.10 \%$, and TOC and TN contents ranged from 0.21 to $10.20 \%$ and 0.01 to $0.34 \%$, respectively. The TOC and TN contents tended to decrease with sediment depth and the fine sediment grained size fractions. The total OC storage in sediments is up to $45 \mathrm{~cm}$ in depth of Dong Rui mangrove forest accounting for $1.26( \pm 0.3) \times 10^{5} \quad \mathrm{Mg} \quad \mathrm{C}$, equivalent to $4.6( \pm 1.2) \times 10^{5} \mathrm{Mg} \mathrm{CO}_{2}$. The $\delta^{13} \mathrm{C}$ values and $\mathrm{C} / \mathrm{N}$ ratios ranged from -27.75 to $-25.84 \%$ o and 15.07 to 46.09 , respectively. The results indicated that sedimentary OC was dominantly originated from the mangrove litters. The proportion of mangrove litters in the sedimentary OC ranged from 44.32 to $79.72 \%$, with an average of $62.4 \%$. The present study also demonstrated that the Dong Rui mangrove forests play an important role in the accumulation process of fine sediments and $\mathrm{OC}$ sequestration. Therefore, conservation of mangrove forests provides not only coastal protection and disaster mitigation and other provision values, but also enhances carbon sequestration and offsetting GHG emissions.

\section{Acknowledgements}

We thank two anonymous reviewers for their critical comments that significantly improved this manuscript from an early version. This research is funded by Vietnam National Foundation for Science and Technology Development (NAFOSTED) under grant number 105.08-2015.18. 


\section{Pham Thao Nguyen, et al./Vietnam Journal of Earth Sciences 38 (2016)}

\section{References}

Alongi, D.M., 2011. Carbon payments for mangrove conservation: ecosystem constraints and uncertainties of sequestration potential. Environmental Science Policy 14, 462-470.

Alongi, D.M., Sasekumar, A., Chong, V.C., Pfitzner, J., Trott, L.A., Tirendi, F., Dixon, P., Brunskill, G.J., 2004. Sediment accumulation and organic material flux in a managed mangrove ecosystem: estimates of land - ocean atmosphere exchange in peninsular Malaysia. Marine Geology 208, 383-402.

Bouillon, S., Connolly, R., Lee, S., 2008. Organic matter exchange and cycling in mangrove ecosystems: recent insights from stable isotope studies. Journal of Sea Research 59, 44-58.

Bouillon, S., Rao, A.V.V.S., Koedam, N., Dahdouh-Guebas, F., Dehairs, F., 2003. Sources of organic carbon in mangrove sediments: variability. Hydrobiologia 495, 33-39.

Christensen, B., 1978. Biomass and primary production of Rhizophora apiculata Bl. in a mangrove in southern Thailand. Aquat Bot 4, 43-52.

Donato, D.C., Kauffman, J.B., Murdiyarso, D., Kurnianto, S., Stidham, M., Kanninen, M., 2011. Mangroves among the most carbon - rich forests in the tropics. Nature Geoscience 4, 293-297.

Furukawa, K., Wolanski, E., 1996. Sedimentation in mangrove forests. Mangroves Salt Marshes 1, 3-10.

Hedges, J.I., Keil, R.G., 1995. Sedimentary organic matter preservation: an assessment and speculative synthesis. Marine Chemistry 49, 137-139.

Hoang Van Tuan, Tran Dang Quy, Nguyen Van Vuong, Mai Trong Nhuan, 2012. Orientation of functional zoning for sustainable use of environment and natural resources in Tien Yen Bay. Vietnam Journal of Earth Sciences 34, 486494 (In Vietnamese).

Kauffman, J.B., Donato, D.C., 2012. Protocols for the measurement, monitoring and reporting of structure, biomass and carbon stocks in mangrove forests. Center for International Forest Research, Bogor, Indonesia, 86 pp.

Kristensen, E., Bouillon, S., Dittmar, T., Marchand, C., 2008. Organic carbon dynamics in mangrove ecosystems: A review. Aquat Bot 89, 201-209.

Lamb, A., Wilson, G., Leng, M., 2006. A review of coastal palaeoclimate and relative sea-level reconstructions using $\delta^{13} \mathrm{C}$ and $\mathrm{C} / \mathrm{N}$ ratios in organic material. Earth Science Reviews 75, 29-57.
Lovelock, C.E., Ruess, R.W., and Feller, I.C., 2011. $\mathrm{CO}_{2}$ efflux from cleared mangrove peat. PLoS ONE 6, 1-4.

Mai Sy Tuan, Nguyen Thi Hong Hanh, 2009. Carbon accumulation of Kandelia obovata (Sheue, Liu \& Yong) plantation in the coastal area of Giao Thuy district, Nam Dinh province. Journal of Biology 31, 57-65 (In Vietnamese).

Nguyen Tai Tue, Luu Viet Dung, Mai Trong Nhuan, Omori, K., 2014. Carbon storage of a tropical mangrove forest in Mui Ca Mau National Park, Vietnam. Catena 121, 119-126.

Nguyen Tai Tue, Hamaoka, H., Sogabe, A., Tran Dang Quy, Mai Trong Nhuan, Omori, K., 2011. The application of $\delta^{13} \mathrm{C}$ and $\mathrm{C} / \mathrm{N}$ ratios as indicators of organic carbon sources and paleoenvironmental change of the mangrove ecosystem from Ba Lat Estuary, Red River, Vietnam. Environmental Earth Sciences 64, 1475-1486.

Nguyen Tai Tue, Nguyen Thi Ngoc, Tran Dang Quy, Hamaoka, H., Mai Trong Nhuan, Omori, K., 2012. A cross-system analysis of sedimentary organic carbon in the mangrove ecosystems of Xuan Thuy National Park, Vietnam. Journal of Sea Research 67, 69-76.

Ong, J.E., 1993. Mangroves - a carbon source and sink. Chemosphere 27, 1097-1107.

Reimers, C.E., Suess, E., 1983. The partitioning of organic carbon fluxes and sedimentary organic matter decomposition rates in the ocean. Marine Chemistry 13, 141-168.

Richard, M., Angus, M., Tim, H., 2011. The potential for mangrove carbon projects in Vietnam. SNV REDD+, Hanoi.

Schumacher, B.A., 2002. Methods for the determination of total organic carbon in soils and sediments. U.S. Environmental Protection Agency, Washington.

Siikamäki, J., Sanchirico, N., Jardine, J., McLaughlin, S., Morris, D.F., 2012. Blue carbon: global options for reducing emissions from the degradation and development of coastal ecosystems. Resources for future, Washington.

Spalding, M., Kainuma, M., and Collins, L., 2010. World atlas of mangroves. Earthscan from Routledge, London.

Tran Dang Quy, Nguyen Tai Tue, 2011. Spatial distribution of total organic carbon (TOC), total nitrogen (TN), TOC/TN ratio, and stable carbon isotopes value $\left(\delta^{13} \mathrm{C}\right)$ in surface sediments of Tien Yen Bay, northeast Vietnam. Vietnam Journal of Earth Sciences 33, 615-624 (In Vietnamese).

Van Santen, P., Augustinus, P., Janssen-Stelder, B., Quartel, S., Nguyen Hoang Tri, 2007. Sedimentation in an estuarine mangrove system. Journal of Asian Earth Sciences 29, 566-575. 